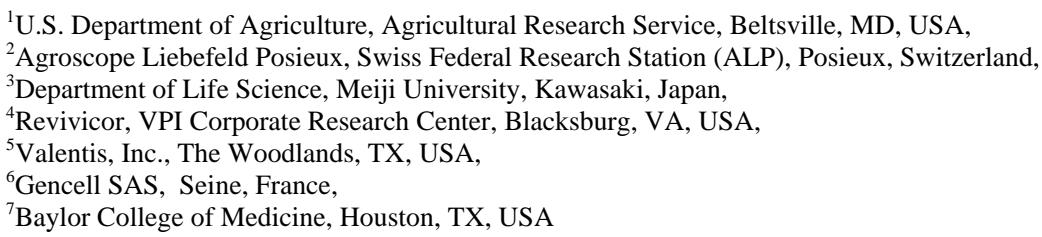

GIUSEPPE BEE ${ }^{1,2}$, VERNON G. PURSEL ${ }^{1,}$, ALVA D. MITCHELL ${ }^{1}$, KIMIAKI MARUYAMA ${ }^{1,3}$, KEVIN D. WELLS ${ }^{1,4}$, MORSE B. SOLOMON ${ }^{1}$, ROBERT J. WALL ${ }^{1}$, MICHAEL E. COLEMAN ${ }^{5,6}$, and ROBERT J. SCHWARTZ ${ }^{7}$

\title{
Carcass composition and skeletal muscle morphology of swine expressing an insulin-like growth factor I transgene ${ }^{\S}$
}

\begin{abstract}
Research was conducted to determine if directing expression of insulin-like growth factor I (IGF1) specifically to striated muscle would enhance lean muscle growth in swine. At $120 \mathrm{~kg} \mathrm{BW}, 25$ transgenic (T) and 26 control (C) pigs were sacrificed to evaluate carcass composition. T-pigs had lower percentages of fat and higher percentages of lean tissues than C-pigs for the overall carcass and each carcass region ( $P \leq 0.002$ for each). Expression of the IGF1 transgene did not alter the percentages of the three fiber types in the five skeletal muscles, however, fiber areas of longissimus dorsi muscle (LM) and serratus ventralis were larger $(P \leq 0.031)$ in T- than in C-pigs. In Tpigs the relative abundance of IGF1 mRNA in gastrocnemius, gluteus medius, LM, and the average for all five skeletal muscles (ASM) was positively $(P \leq 0.011)$ correlated with percentage of carcass lean $(r=+0.597$ to 0.804), whereas the relative abundance of IGF1 mRNA in the LM and the ASM was negatively $(P \leq 0.047)$ correlated with average backfat ( $r=-0.546$ and -0.488 , respectively). Based on these results we conclude that expression of IGF1 specifically in skeletal muscle had a positive effect on carcass composition of swine.
\end{abstract}

Key Words: Insulin-like growth factor I; Growth hormone; Pigs; Growth; Carcass composition, Muscle fiber

\section{Zusammenfassung}

Titel der Arbeit: Schlachtkörperzusammensetzung und Skelettmuskelmorphologie bei IGF1 transgenen Schweinen

Das Ziel des Experiments war zu prüfen, ob über die gezielte Erhöhung der Expression von Insulin Wachstumsfaktor I (IGF1) im gestreiften Muskel der Muskelansatz beim Schwein verbessert werden kann. Bei einem Schlachtgewicht von $120 \mathrm{~kg}$, wurden 25 IGF1 transgene (T) und 26 Kontrollschweine (K) geschlachtet und deren Schlachtkörperzusammensetzung bestimmt. Sowohl bezogen auf den gesamten Schlachtkörper als auch bezogen auf die einzelnen Teilstücke wiesen die T-Schweine einen geringeren $(P \leq 0.002)$ Fett- und einen höheren $(P \leq 0.001)$ Muskelansatz auf. Die Verteilung der drei Muskelfasertypen in den fünf untersuchten Muskeln war zwischen den T- und K-Schweinen nicht unterschiedlich $(P \geq 0.114)$. Die Muskelfasern im langen Rückenmuskel (LM) und im serratus ventralis von T-Schweinen waren jedoch grösser $(P \leq 0.031)$ als von KSchweinen. Deutlich positive $(P \leq 0.011)$ Beziehungen bestanden zwischen dem Magerfleischanteil des Schlachtkörpers und der relativen Abundanz der IGF1 mRNA im gastrocnemius $(r=0.804)$, gluteus medius $(r=$ 0.712), LM $(r=0.686)$, und im Mittel der fünf Muskeln $(r=0.796)$. Hingegen war die relative Abundanz der IGF1 mRNA im LM $(r=-0.546)$ und im Mittel der fünf Muskeln $(r=-0.488)$ negativ $(P \leq 0.047)$ mit dem Anteil Auflagenfett des Schlachtkörpers korreliert. Die vorliegenden Ergebnisse zeigen, dass die erhöhte Expression von IGF1 im Muskelgewebe die Schlachtkörperzusammensetzung positiv beeinflusst.

Schlüsselwörter: Insulin Wachstumsfaktor I, Wachstumshormon, Schwein, Wachstum, Schlachtkörperzusammensetzung, Muskelfasern

${ }^{\S}$ Mention of trade names or companies does not constitute an implied warranty or endorsement by the USDA or the authors. 


\section{Introduction}

Although growth is primarily regulated by growth hormone $(\mathrm{GH})$, many of its effects are mediated by insulin-like growth factor-I (IGF1), a single-chain mitogenic polypeptide. Recent research with liver-specific IGF1 deficient mice has provided direct evidence that IGF1 acts locally in a paracrine/autocrine fashion to mediate $\mathrm{GH}$ rather than by the endocrine mode in stimulating growth of somatic tissues (SJOGREN et al., 1999; YAKAR et al., 1999).

Administration of IGF1 to pigs (WALTON et al., 1995; KLINDT et al., 1998) and lambs (COTTAM et al., 1992; MIN et al., 1996) did not enhance lean body mass. KLINDT et al. (1998) observed an increase in adipose deposition in pigs injected twice daily with recombinant (r)hIGF1 for four weeks even though serum IGF1 was elevated by $60 \%$ compared to untreated pigs. Lack of growth enhancement in these studies may be the unintended consequence of elevated plasma IGF1 inducing negative feedback of IGF1 on the hypothalamus, which would depress GH secretion from the pituitary (KLINDT et al., 1998).

To avoid the consequences that might ensue from depressed GH secretion, Coleman et al. (1995) constructed a skeletal $\alpha$-actin-hIGF1 transgene to direct IGF1 expression specifically in striated muscle of transgenic mice. Their objective was to direct sufficient expression of IGF1 in muscle to act as a paracrine agent without altering plasma IGF1 concentration sufficiently to depress GH synthesis and secretion. The skeletal $\alpha$-actin-hIGF1 transgene was subsequently transferred into swine to investigate its potential for improving productivity. The production and preliminary characterizations of the founder IGF1 transgenic pigs have been described (PURSEL et al., 1999). The purpose of the present paper is to further elucidate the impact of IGF1 expression on the carcass characteristics and muscle fiber morphology of the progeny from six transgenic founder swine.

\section{Material and Methods}

\section{Animals}

The 26 control (12 gilts and 14 boars) and 25 transgenic pigs (11 gilts and 14 boars) used in this study were first generation (G1) progeny of 11 litters that resulted from the mating of three IGF1 founder transgenic gilts with three unrelated non-transgenic boars (Orange Line Hybrid, DeKalb Swine Breeders, Inc., DeKalb, Ill.) and three IGF1 transgenic boars with two or three unrelated non-transgenic DK-43 hybrid gilts (DeKalb Swine Breeders, Inc., DeKalb, Ill.). The founder transgenic pigs were produced with a fusion gene composed of avian skeletal $\alpha$-actin (SK733) regulatory sequences and a cDNA encoding human IGF1 as described by COLEMAN et al. (1995). Presence of the IGF1 transgene was established by Southern blot hybridization analysis of DNA from tail biopsies.

Details regarding the housing, nutrition, management, and experimental conditions pigs were exposed to before slaughter are described in a separate paper (PURSEL et al., 2004). The mean live weight at slaughter differed for control and transgenic gilts (118.3 vs. $121.8 \mathrm{~kg}, P<0.05)$ but not for the boars (120.7 vs. $120.4 \mathrm{~kg}, P>0.05)$. Control and transgenic gilts were older $(P<0.05)$ at slaughter $(200.8$ and $206.7 \mathrm{~d})$ than control and transgenic boars (187.9 and $197.9 \mathrm{~d}$; age of transgenic and controls at slaughter did not differ $(P>0.05)$. The Beltsville Area Institutional Animal Care and Use Committee approved experimental protocols used in this research. 


\section{Carcass evaluation}

When pigs weighed about $120 \mathrm{~kg}$ they were transported to the Beltsville ARS abattoir (establishment \# 68), electrically stunned and exsanguinated, the head and viscera were removed, and the carcass split at the midline. The hair and feet remained on the carcass. The right half of each carcass was chilled for $24 \mathrm{~h}$, weighed, and then scanned by dual energy x-ray absorptiometry (DXA) using a Lunar DPX-L densitometer (Madison, WI). The DXA total body results provided measurements of fat, lean, bone mineral, and total tissue mass. After the DXA scan was performed, each carcass was homogenized by grinding as described previously (MITCHELL et al., 1994). Homogenized tissue samples were analyzed for the content of fat by chloroformmethanol extraction (FOLCH et al., 1957) $(\mathrm{CV}=0.9 \%)$, of protein by Kjeldahl nitrogen determination $(\mathrm{CV}=2.4 \%)$ and of water by lyophilization $(\mathrm{CV}=1.9 \%)$. To compare DXA bone mineral content to total carcass ash by combustion, the total carcass ash content was corrected for the ash content of $0.85 \%$ for boneless pork meat (JEBB et al., 1995).

The DPX-L (adult mode) software allows manual regional analysis, providing fat, lean, bone mineral content (BMC), and total tissue mass for each user defined region. Using this option, the DXA scan results were analyzed by dividing the carcass into four regions: ham, shoulder, loin, and side (belly). The following prediction equations for conversion of DXA fat values were derived from the data published by MITCHELL et al. (1998), and percentage of DXA bone was based on the $24.14 \%$ ash content of pork bones reported by FIELD et al. (1974).

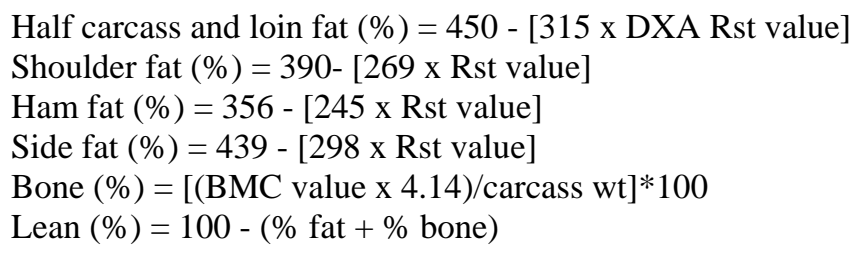

Total carcass length was measured. The loin eye area (LEA) was determined at the level of the 10th rib of the longissimus muscle (LM), fat thickness (P2BF) over the LM was measured at $65 \mathrm{~mm}$ from the midline at the 10th rib, and average backfat thickness (ABF) was determined from midline measurements at the first and last ribs and at the last lumbar vertebra.

\section{Tissue Sampling and Histochemical Methods}

After the pigs were eviscerated the adrenals, heart, liver, kidneys, ovaries, spleen, and testis were weighed, and 5-g samples of heart and liver were wrapped in aluminum foil, frozen in liquid nitrogen, and stored at $-70{ }^{\circ} \mathrm{C}$ until mRNA analyses were performed. Each stomach was emptied, rinsed under tap water and the esophageal region visually evaluated by a modification of the scoring system described by EISMANN and ARGENZIO (1999). Degree of erosion and ulceration was scored on a scale of 1 to 6 , with 1 having smooth surface throughout the pars esophagea, 2 showed some cornification and papillae elongation, 3 having extensive cornification and papillae development, 4 having some tissue erosion, 5 having extensive tissue erosion and small ulceration, and 6 being completely ulcerated. 
Five muscles were removed from the left side of each carcass for histochemical and RNA analyses within 15 min after exsanguination. The torso muscles included LM and serratus ventralis (SV); the hind limb muscles included gastrocnemius (GC), gluteus medius (GM), and semitendinosus (ST). The weight, girth, and length of each ST muscle were measured after muscle excision. Muscle samples for fiber determination were taken from the central region of the SV, GC, GM, from the center of the dark portion of the ST, and the anterior part of the 12th rib location of the LM. One piece (approximately $1 \mathrm{~cm} \times 1 \mathrm{~cm} \mathrm{x} 3 \mathrm{~cm}$ ) of each muscle was immediately fixed on a labeled flat stick, rolled in talcum powder, and frozen in liquid nitrogen, and a 5-g sample from the same vicinity of each muscle was collected, wrapped in aluminum foil, and frozen in liquid nitrogen. Both sets of samples were stored at $-70{ }^{\circ} \mathrm{C}$ until muscle morphology and mRNA analyses were performed.

For fiber determination, frozen muscles samples were equilibrated to $-25{ }^{\circ} \mathrm{C}$, cut from stick, and trimmed to facilitate transverse sectioning. Samples were mounted on a cryostat chuck with a few drops of tissue freezing medium (Triangle Biomedical Science, Durham, NC). Six-micrometer-thick sections were cut using a Cryostat 2800 Frigocut-E (Reichert-Jung, Cambridge Instruments, Deerfield, IL). Sections were mounted on glass microscopic slides and were allowed to air-dry for $30 \mathrm{~min}$. The sections were treated with the combination succinic dehydrogenase and acid myofibrillar ATPase staining procedure (SOLOMON and DUNN, 1988).

The stained sections were observed at 200X with a Zeiss Confocal microscope in transmitted light mode (Carl Zeiss MicroImaging, Inc., Thornwood, NY). Muscle fibers were classified as slow oxidative (SO), fast oxidative glycolytic (FOG), and fast glycolytic (FG) based on the stain reaction. The SO fibers showed the darkest and FG the lightest staining intensity. Four random fields at different location within a slide of each muscle sample were captured as TIF-files and analyzed with the Kontron 300 image analysis software (Kontron Elektronik Corp., Newport Beach, CA). To minimize the incidence of measuring intrafasicular terminations of myofibers, only fibers larger than $1000 \mu^{2}$ were included in calculations. Fiber type distribution was calculated in two ways. One method expresses the percentage of each fiber type to the total of all measured fibers (FNP). The other method expresses the percentage of the total measured area relative to the area of each fiber type (FAP). Numbers of fibers in ST was estimated by extrapolating the number of fibers in a known area under the microscope to the girth of the ST at the midpoint between attachments.

\section{Muscle IGF1 mRNA}

A 772 base pair PstI fragment of hIGF1 cDNA (JANSEN et al., 1983) was used for detection of IGF1 mRNA. Total RNA was isolated from guanidine isothionate homogenates using phenol-chloroform extraction and ethanol precipitation. For Northern blot hybridization, $20 \mu \mathrm{g}$ of total RNA was denatured at $55{ }^{\circ} \mathrm{C}$ and fractionated on $1 \%$ agarose $-0.66 \mathrm{M}$ formaldehyde gel under $3.5 \mathrm{volts} / \mathrm{cm}$ for $75 \mathrm{~min}$. The RNA on the gel was then transferred onto nylon membranes (Nytran ${ }^{\circledR}$, Schleicher \& Schuell, Keene, NH) by the downward transfer (Turboblotter ${ }^{\mathrm{TM}}$, Schleicher \& Schuell, Keene, $\mathrm{NH}$ ) and immobilized by UV cross-linking. Blots were hybridized with a Digoxigenin (DIG)-labeled hIGF1 probe (Boehringer Mannheim, Indianapolis, IN) at $50{ }^{\circ} \mathrm{C}$ overnight. After the membrane was washed twice for $5 \mathrm{~min}$ in $2 \mathrm{X}$ SSC $0.5 \%$ SDS at room temperature and washed twice for $15 \mathrm{~min}$ in $0.5 \mathrm{X}$ SSC - $0.1 \%$ SDS 
at $68{ }^{\circ} \mathrm{C}$, it was incubated in a blocking solution, followed by an anti-DIG antibodyalkaline phosphate conjugate solution (Boehringer Mannheim, Indianapolis, IN). IGF1 mRNA was visualized by applying a fluorescence substrate, ECFTM (Amersham Phamacia Biotech, Piscataway, NJ) on the membrane and incubating at room temperature for several hours. A Fluoroimager ${ }^{\mathrm{TM}}$ (STORM 860, Molecular Dynamics, Sunnyvale, CA) was used to determine signal intensity. The intensity of IGF1 mRNA signal was normalized for $\beta$-tubulin for comparison.

\section{Shear Force Tenderness}

After the muscle fiber and mRNA tissue samples were removed from the excised LM, the remaining portion $\sim 30 \mathrm{~cm}$ in length was vacuum packaged and refrigerated $\left(2{ }^{\circ} \mathrm{C}\right)$ through $5 \mathrm{~d}$ postmortem and then frozen and stored at $-20{ }^{\circ} \mathrm{C}$ for subsequent shear force determinations. Two chops ( $2.5 \mathrm{~cm}$ in thickness) from each frozen LM section were removed and thawed for 18 to $20 \mathrm{~h}$ at $2{ }^{\circ} \mathrm{C}$. Chops were cooked (broiled) to an internal temperature of $75{ }^{\circ} \mathrm{C}$, turning once at $40^{\circ} \mathrm{C}$, using Farberware Open-Hearth broilers (Model 350A, Farberware Co., Bronx, NY). Internal temperature was monitored using iron-constantan thermocouples attached to a recording potentiometer. Cooking yields were recorded (weight of chop before and after being cooked). Chops were allowed to cool to room temperature $\left(25^{\circ} \mathrm{C}\right)$ before coring. A minimum of four cores $(1.3 \mathrm{~cm}$ in diameter) were removed from each chop, parallel to the muscle-fiber orientation, and these cores were used for shear force determination using a WarnerBratzler shear test cell mounted on a Food Texture Corp. (FTC) texture measurement system (Model TMS-90, FTC, Chantilly, VA) using a $3.18 \mathrm{~mm}$ thick blade, Vnotched, and crosshead speed of $25 \mathrm{~cm} / \mathrm{min}$.

\section{Statistical Analysis}

Variables for carcass composition, organ, ST weights, shear force, cooking yield, and erosion score were analyzed as a two factor general linear mixed model using the mixed procedure of SAS. Gene, sex, and interaction were fixed effects, with litter as a random factor. Half carcass weight and live weight were used as covariates for carcass composition measures and organ weights, respectively. Least squares means for gene within sex were separated by the PDIFF option of SAS when gene $x$ sex ( $G \times$ S) interactions were significant.

All statistical analyses were conducted using the SAS System version 6.12 (SAS Inst. Inc., Cary, NC). The fiber area variable was analyzed for each muscle as a three-factor split plot mixed model using the mixed procedure of SAS. Gene and sex were the whole plot fixed effects, muscle fiber type the subplot fixed effect, with litter and litter $\mathrm{x}$ gene $\mathrm{x}$ sex as random factors. When it was necessary to correct for variance heterogeneity, the data was grouped either by gender or gene and separate variance estimates for each of the groups were used in the analysis. Fiber type distribution variables were analyzed for each fiber type and muscle as a two factor general linear mixed model using the mixed procedure of SAS. Gene and sex were fixed effects, with litter as a random factor. When it was necessary to correct for variance heterogeneity, the data was grouped by sex and separate variance estimates for each group were used in the analysis.

Pearson's correlation coefficients were calculated between normalized values for muscle IGF1 mRNA abundance, muscle fiber area, and carcass composition measures 
of the transgenic pigs, between normalized values for heart IGF1 mRNA abundance and organ weights, and between the mean of IGF1 mRNA abundance for the five skeletal muscles and organ weights. Normalized IGF1 mRNA abundance for heart and the five skeletal muscles were analyzed by the GLM procedure of SAS. Muscle, sex, line, and interactions were fixed effects. Since interactions were not significant $(P>$ 0.10 ), they were excluded from the model. Least squares means for heart vs. skeletal muscles were compared by orthogonal contrast, and least squares means among skeletal muscles were separated by the PDIFF option of SAS.

\section{Results}

\section{DXA Evaluation of Half Carcasses}

The effects of the IGF1 transgene on carcass composition as assessed by DXA analysis of the right half of each carcass and the four major primal cut regions are summarized in Table 1 . The percentage of carcass fat was lower $(P \leq 0.002)$ and the percentage of lean tissue was higher $(P \leq 0.001)$ in transgenic than control pigs for the overall carcass as well as in each of the separate carcass regions.

Table 1

Fat, lean and bone content from DXA analyses of half carcasses of control and IGF1 transgenic boars and gilts [Fett-, Muskel- und Knochenanteil in den Schlachtkörperhälften von weiblichen und intakten männlichen Kontroll- und IGF1-transgenen Schweinen bestimmt mittels DXA-Analyse]

\begin{tabular}{lcrrrrrrr} 
& \multicolumn{3}{c}{ Gilts } & \multicolumn{3}{c}{ Boars } & \multicolumn{2}{c}{$P$-values } \\
\cline { 2 - 8 } Item & Control & Transgenic & Control & Transgenic & SEM & Gene & Sex & Gene x Sex \\
\hline Half Carcass & & & & & & & & \\
Fat (\%) & 33.0 & 29.7 & 27.5 & 25.6 & 0.8 & $<0.001$ & $<0.001$ & 0.317 \\
Lean (\%) & 54.2 & 58.2 & 60.3 & 62.2 & 0.8 & $<0.001$ & $<0.001$ & 0.137 \\
Bone (\%) & 12.8 & 12.1 & 12.2 & 12.2 & 0.2 & 0.110 & 0.221 & 0.144 \\
Shoulder & & & & & & & & \\
Fat (\%) & 33.4 & 30.7 & 29.2 & 27.5 & 0.7 & $<0.001$ & $<0.001$ & 0.386 \\
Lean (\%) & 47.8 & 52.1 & 54.1 & 55.9 & 0.9 & 0.001 & $<0.001$ & 0.140 \\
Bone (\%) & 18.9 & 17.2 & 16.7 & 16.7 & 0.4 & 0.072 & 0.004 & 0.067 \\
Ham & & & & & & & & \\
Fat (\%) & 30.5 & 28.7 & 26.7 & 25.3 & 0.6 & 0.002 & $<0.001$ & 0.663 \\
Lean (\%) & 53.7 & 57.5 & 59.1 & 60.7 & 0.8 & 0.001 & $<0.001$ & 0.175 \\
Bone (\%) & 15.8 & 13.9 & 14.2 & 14.0 & 0.6 & 0.064 & 0.208 & 0.105 \\
Loin & & & & & & & & \\
Fat (\%) & 32.8 & 29.3 & 27.6 & 25.4 & 0.9 & $<0.001$ & $<0.001$ & 0.370 \\
Lean (\%) & 55.4 & 58.8 & 61.8 & 63.5 & 0.9 & 0.001 & $<0.001$ & 0.200 \\
Bone (\%) & 11.9 & 11.9 & 10.6 & 11.1 & 0.4 & 0.363 & 0.004 & 0.408 \\
Side & & & & & & & & \\
Fat (\%) & 47.3 & 44.0 & 41.2 & 39.2 & 0.9 & 0.001 & $<0.001$ & 0.388 \\
Lean (\%) & 50.2 & 53.7 & 56.5 & 58.5 & 0.9 & $<0.001$ & $<0.001$ & 0.302 \\
Bone (\%) & 2.5 & 2.3 & 2.3 & 2.4 & 0.2 & 0.585 & 0.698 & 0.474 \\
\hline
\end{tabular}

Carcass fat was 10 and $6.9 \%$ lower $(P<0.001)$ in transgenic gilts and boars, respectively, compared to sibling controls. Transgenic gilts and boars had 7.3 and $3.2 \%$ more $(P<0.001)$ carcass lean, respectively, than sibling controls. The percentage of carcass bone did not $(P=0.110)$ differ between transgenic and control pigs. In both the shoulder and loin regions boars had less $(P=0.004)$ bone percentage than gilts. The percentage of the total carcass weight contained in each of the separate regions did not $(P>0.05)$ differ for transgenic and control pigs. 


\section{Direct Carcass Measurements}

Carcass dressing percentage, average backfat, P2 backfat depths, and carcass lipid concentration were lower $(P \leq 0.026)$ and carcass water was higher $(P=0.024)$ in transgenic pigs than in the controls (Table 2$)$. Gilts had higher $(P<0.001)$ dressing percentage, less $(P \leq 0.001)$ subcutaneous adipose and overall carcass lipids and higher $(P<0.001)$ percentage carcass water than boars. These differences tended to be larger between transgenic and control gilts than between transgenic and control boars (G x S interaction: $P \leq 0.098$ ). Total carcass length and percentage of total carcass protein did not $(P \geq 0.113)$ differ between transgenic and control pigs. Loin eye areas were $14.5 \%$ larger $(P<0.001)$ in transgenic gilts and boars than sibling controls. Shear force values and cooking yield for LM did not $(P \geq 0.182)$ differ between transgenic and control pigs.

\section{Table 2}

Carcass and backfat measurements, nutrient composition of ground carcasses, and longissimus muscle (LM) shear force and cooking yield of control and IGF1 transgenic boars and gilts [Schlachtkörpermerkmale, Nährstoffzusammensetzung des Schlachtkörpers, Kochverluste und Scherkraft bestimmt im langen Rückenmuskel von weiblichen und intakten männlichen Kontroll- und IGF1-transgenen Schweinen]

\begin{tabular}{lcccccccc}
\hline & \multicolumn{3}{c}{ Gilts } & \multicolumn{3}{c}{ Boars } & \multicolumn{3}{c}{$P$-values } \\
\cline { 2 - 9 } Item & Control & Transgenic & Control & Transgenic & SEM & Gene & Sex & Gene x Sex \\
\hline Carcass length (mm) & 841 & 846 & 843 & 847 & 5.7 & 0.455 & 0.807 & 0.920 \\
Dressing (\%) & 77.7 & 75.3 & 74.8 & 74.4 & 0.5 & 0.012 & 0.001 & 0.070 \\
ABF (mm) & 33.7 & 31.1 & 29.2 & 25.8 & 1.6 & 0.016 & $<0.001$ & 0.733 \\
P2BF (mm) & $23.9^{\mathrm{d}}$ & $15.0^{\mathrm{e}}$ & $16.5^{\mathrm{f}}$ & $12.9^{\mathrm{g}}$ & 1.3 & $<0.001$ & 0.001 & 0.049 \\
LEA (cm $)^{\mathrm{c}}$ & 31.7 & 38.0 & 34.5 & 37.8 & 1.4 & $<0.001$ & 0.248 & 0.180 \\
Lipid (\%) & 32.6 & 28.9 & 25.7 & 25.2 & 1.1 & 0.026 & $<0.001$ & 0.086 \\
Water (\%) & 48.4 & 51.4 & 53.7 & 54.1 & 0.9 & 0.024 & $<0.001$ & 0.098 \\
Protein (\%) & 15.4 & 16.0 & 16.2 & 16.4 & 0.3 & 0.113 & 0.053 & 0.561 \\
Shear force (N) & 76.5 & 72.6 & 74.5 & 71.6 & 2.9 & 0.182 & 0.611 & 0.923 \\
Cooking yield (\%) & 65.8 & 66.6 & 65.6 & 66.2 & 1.0 & 0.465 & 0.748 & 0.889 \\
\hline
\end{tabular}

${ }^{\text {a }}$ Average backfat thickness at midline measured at first and last ribs and at last lumbar vertebra.

${ }^{\mathrm{b}}$ Fat thickness over the LM at the 10th rib measured $65 \mathrm{~mm}$ from the midline.

${ }^{\mathrm{c}}$ Loin eye area at 10 th rib.

${ }^{\text {de }}$ Within a row and within gilts, means without a common superscript letter differ $(P<0.05)$.

${ }^{\mathrm{fg}}$ Within a row and within boars, means without a common superscript letter differ $(P<0.05)$.

Table 3

Organ weights and stomach erosion score of of control and IGF1 transgenic boars and gilts.[Organgewichte und Bewertungsnote der Magenerosion bei weiblichen und intakten männlichen Kontroll- und IGF1-transgenen Schweinen]

\begin{tabular}{|c|c|c|c|c|c|c|c|c|}
\hline \multirow[b]{2}{*}{ Organ } & \multicolumn{2}{|c|}{ Gilts } & \multicolumn{2}{|c|}{ Boars } & \multirow[b]{2}{*}{ SEM } & \multicolumn{3}{|c|}{$P$-values } \\
\hline & Control & Transgenic & Control & Transgenic & & Gene & Sex & $\begin{array}{l}\text { Gene } x \\
\text { Sex }\end{array}$ \\
\hline Adrenal (g) & 5.3 & 5.8 & 5.1 & 5.1 & 0.2 & 0.208 & 0.041 & 0.177 \\
\hline Heart (gm) & 354 & 377 & 385 & 420 & 15 & 0.030 & 0.008 & 0.659 \\
\hline Kidney (gm) & 339 & 401 & 432 & 452 & 19 & 0.009 & $<0.001$ & 0.165 \\
\hline Liver (gm) & 1591 & 1540 & 1703 & 1718 & 47 & 0.661 & 0.002 & 0.444 \\
\hline Ovary (g) & 9.5 & 9.8 & - & - & 1.6 & 0.871 & - & - \\
\hline Spleen (gm) & 185 & 188 & 185 & 194 & 12 & 0.614 & 0.768 & 0.777 \\
\hline Testis (g) & - & - & 551 & 657 & 54 & 0.181 & - & - \\
\hline Erosion score $^{\mathrm{a}}$ & 3.0 & 3.0 & $2.3^{\mathrm{b}}$ & $3.8^{\mathrm{c}}$ & 0.4 & 0.053 & 0.906 & 0.036 \\
\hline
\end{tabular}

${ }^{\text {a }}$ Pars esophageal region of stomach was scored on scale of 1 (smooth) to 6 (frank ulceration).

${ }^{\text {bc }}$ Within a row and within boars, means without a common superscript letter differ $(P<0.05)$.

\section{Organ Weights and Stomach Erosion Scores}

The hearts and kidneys of the transgenic pigs were heavier $(P \leq 0.030)$ than those of the control siblings and were heavier $(P \leq 0.008)$ in boars than gilts (Table 3$)$. Weights 
of adrenals, liver, ovaries, spleen, and testis were similar $(P \geq 0.181)$ for transgenic and control pigs but the adrenal was lighter $(P \leq 0.041)$ and liver was heavier $(P=$ 0.002) in boars than in gilts.

The erosion scores of pars esophageal region of the stomach were higher in transgenic boars than in control boars, but erosion scores did not differ among gilts ( $\mathrm{G} \times \mathrm{S}$ interaction, $P=0.036$ ).

\section{Fiber Type Distribution}

The transgenic and control pigs did not $(P \geq 0.114)$ differ in the percentage of each fiber type for the GM, LM, ST, and SV regardless of whether the percentages were based on the FNP (Table 4) or FAP (Table 5). In the GC muscle transgenic gilts had a lower FAP of FOG fibers and a higher FAP of FG fibers than the control gilts whereas the reverse occurred in transgenic and control boars ( $\mathrm{G} \times \mathrm{S}$ interaction; $P \leq 0.025$ ).

Table 4

Fiber type distribution expressed as $\mathrm{FNP}^{\mathrm{a}}$ in five skeletal muscles of control and IGF1 transgenic pigs [Verteilung der Muskelfasertypen ausgedrückt als FNP (Anzahl der einzelnen Muskelfasertypen ausgedrückt in Prozent der totalen Anzahl Muskelfasern) in den fünf Muskeln von weiblichen und intakten männlichen Kontroll- und IGF1-transgenen Schweinen]

\begin{tabular}{|c|c|c|c|c|c|c|c|c|}
\hline \multirow[t]{2}{*}{ Muscle $^{b}$} & \multirow{2}{*}{$\begin{array}{l}\text { Fiber } \\
\text { type }\end{array}$} & \multicolumn{2}{|c|}{ Gilts } & \multicolumn{2}{|c|}{ Boars } & \multicolumn{2}{|c|}{$P$-values } & \multirow[b]{2}{*}{ Gene x Sex } \\
\hline & & Control & Transgenic & Control & Transgenic & Gene $^{c}$ & Sex $^{\mathrm{d}}$ & \\
\hline \multirow[t]{3}{*}{ GC } & $\mathrm{SO}$ & 31.6 & 31.1 & 30.5 & 30.3 & 0.950 & 0.567 & 0.644 \\
\hline & FOG & 30.4 & 25.2 & 28.8 & 32.0 & 0.752 & 0.302 & 0.027 \\
\hline & $\mathrm{FG}^{\mathrm{e}}$ & 38.0 & 43.6 & 40.7 & 37.6 & 0.575 & 0.479 & 0.254 \\
\hline \multirow[t]{3}{*}{ GM } & $\mathrm{SO}^{\mathrm{f}}$ & 15.3 & 15.9 & 16.1 & 15.9 & 0.159 & 0.759 & 0.523 \\
\hline & FOG $^{\mathrm{e}}$ & 19.5 & 23.0 & 27.7 & 26.1 & 0.237 & 0.017 & 0.584 \\
\hline & FG & 65.3 & 62.0 & 56.3 & 58.0 & 0.460 & 0.019 & 0.079 \\
\hline \multirow[t]{3}{*}{ ST } & $\mathrm{SO}^{\mathrm{f}}$ & 41.3 & 46.0 & 44.2 & 45.9 & 0.142 & 0.540 & 0.489 \\
\hline & FOG $^{\mathrm{f}}$ & 39.1 & 37.1 & 37.6 & 37.2 & 0.583 & 0.776 & 0.720 \\
\hline & $\mathrm{FG}^{\mathrm{f}}$ & 19.8 & 17.1 & 18.0 & 16.8 & 0.327 & 0.614 & 0.698 \\
\hline \multirow[t]{3}{*}{ LM } & SO & 10.6 & 10.5 & 11.0 & 10.5 & 0.825 & 0.456 & 0.819 \\
\hline & FOG & 16.3 & 15.7 & 18.9 & 16.6 & 0.332 & 0.057 & 0.448 \\
\hline & $\mathrm{FG}^{\mathrm{e}}$ & 73.0 & 73.8 & 70.2 & 72.8 & 0.724 & 0.495 & 0.979 \\
\hline \multirow[t]{3}{*}{ SV } & SO & 35.1 & 28.6 & 33.6 & 34.6 & 0.311 & 0.312 & 0.194 \\
\hline & FOG $^{\mathrm{f}}$ & 26.1 & 27.7 & 27.6 & 28.7 & 0.520 & 0.408 & 0.913 \\
\hline & FG & 38.7 & 43.7 & 38.7 & 36.6 & 0.504 & 0.257 & 0.143 \\
\hline
\end{tabular}

${ }^{a}$ FNP: fiber number percentage is the ratio of the number each fiber type to the total fibers counted.

${ }^{\mathrm{b}} \mathrm{GC}=$ gastrocnemius, $\mathrm{GM}=$ gluteus medius, $\mathrm{ST}=$ semitendinosus, $\mathrm{LM}=$ longissimus, $\mathrm{SV}=$ serratus ventralis.

${ }^{\mathrm{c}}$ Control vs. IGF1 transgenic.

${ }^{\mathrm{d}}$ Gilts vs. boars.

e The data were grouped by sex and separate variance estimates were used in the analysis.

${ }^{\mathrm{f}}$ The data were grouped by treatment and separate variance estimates were used in the analysis.

Fiber type distribution based on FNP was similar $(P \geq 0.057)$ for gilts and boars in the GC, ST, LM, and SV muscles. However, in the GM muscle, boars had a higher $(P=$ 0.017) percentage of FOG fibers and lower $(P=0.019)$ percentage of FG fibers than the gilts. When fiber type distribution was based on FAP gilts and boars had similar $(P$ $\geq 0.053$ ) percentages in GC, GM, and ST muscles. However, in gilts LM had a higher $(P=0.017)$ percentage of FG fibers and lower $(P=0.017)$ percentage of FOG fibers than in boars, and in the SV muscle boars had a higher $(P=0.044)$ percentage of SO fibers than gilts. Among muscles, the percentage of each fiber type varied considerably for both FNP and FAP analyses. 
Table 5

Fiber type distribution expressed as $\mathrm{FAP}^{\mathrm{a}}$ in five skeletal muscles of control and IGF1 transgenic pigs [Verteilung der Muskelfasertypen ausgedrückt als FAP (totale Fläche der einzelnen Muskelfasertypen ausgedrückt in Prozent der totalen Muskelfaserfläche) in den fünf Muskeln von weiblichen und intakten männlichen Kontroll- und IGF1 transgenen Schweinen]

\begin{tabular}{|c|c|c|c|c|c|c|c|c|}
\hline \multirow[t]{2}{*}{ Muscle $^{\mathrm{b}}$} & \multirow{2}{*}{$\begin{array}{l}\text { Fiber } \\
\text { Type }\end{array}$} & \multicolumn{2}{|c|}{ Gilts } & \multicolumn{2}{|c|}{ Boars } & \multicolumn{2}{|c|}{$P$-values } & \multirow[b]{2}{*}{ Gene x Sex } \\
\hline & & Control & Transgenic & Control & Transgenic & Gene $^{c}$ & $\operatorname{Sex}^{\mathrm{d}}$ & \\
\hline \multirow[t]{3}{*}{ GC } & $\mathrm{SO}$ & 24.5 & 26.2 & 22.2 & 22.6 & 0.499 & 0.248 & 0.474 \\
\hline & FOG & 27.3 & 20.4 & 22.0 & 27.7 & 0.984 & 0.438 & 0.010 \\
\hline & $\mathrm{FG}^{\mathrm{e}}$ & 48.3 & 53.4 & 55.9 & 49.6 & 0.940 & 0.413 & 0.025 \\
\hline \multirow[t]{3}{*}{ GM } & $\mathrm{SO}^{\mathrm{e}}$ & 11.6 & 9.9 & 11.3 & 10.5 & 0.181 & 0.775 & 0.854 \\
\hline & FOG & 14.3 & 16.8 & 18.9 & 20.6 & 0.461 & 0.127 & 0.699 \\
\hline & $\mathrm{FG}^{\mathrm{e}}$ & 74.0 & 73.2 & 69.9 & 69.0 & 0.443 & 0.053 & 0.608 \\
\hline \multirow[t]{3}{*}{ ST } & SO & 45.6 & 49.4 & 44.6 & 48.6 & 0.114 & 0.583 & 0.769 \\
\hline & FOG & 32.8 & 31.6 & 35.0 & 33.1 & 0.668 & 0.564 & 0.913 \\
\hline & $\mathrm{FG}^{\mathrm{e}}$ & 21.3 & 19.0 & 20.5 & 17.9 & 0.365 & 0.575 & 0.946 \\
\hline \multirow[t]{3}{*}{ LM } & $\mathrm{SO}^{\mathrm{e}}$ & 7.2 & 8.2 & 7.4 & 9.4 & 0.199 & 0.580 & 0.639 \\
\hline & FOG & 10.3 & 8.9 & 12.9 & 11.7 & 0.231 & 0.017 & 0.886 \\
\hline & $\mathrm{FG}$ & 82.4 & 82.8 & 79.7 & 78.7 & 0.959 & 0.017 & 0.818 \\
\hline \multirow[t]{3}{*}{ SV } & $\mathrm{SO}^{\mathrm{e}}$ & 33.2 & 28.7 & 33.8 & 37.5 & 0.612 & 0.044 & 0.060 \\
\hline & FOG $^{\mathrm{f}}$ & 21.3 & 20.7 & 19.7 & 21.5 & 0.998 & 0.899 & 0.291 \\
\hline & $\mathrm{FG}^{\mathrm{e}}$ & 45.8 & 50.6 & 46.4 & 41.6 & 0.641 & 0.423 & 0.344 \\
\hline
\end{tabular}

a FAP: fiber area percentage is the ratio of the total cross-sectional area of each fiber type to the total fiber area measured.

b $\mathrm{GC}=$ gastrocnemius, $\mathrm{GM}$ = gluteus medius, $\mathrm{ST}=$ semitendinosus, $\mathrm{LM}=$ longissimus, $\mathrm{SV}=$ serratus ventralis.

c Control vs. IGF1 transgenic.

d Gilts vs. boars.

e The data were grouped by treatment and separate variance estimates were used in the analysis.

$\mathrm{f}$ The data were grouped by sex and separate variance estimates were used in the analysis.

Table 6

Fiber area $\left(\mu^{2}\right)$ in five muscles of control and IGF1 transgenic pigs [Die Fläche der drei Muskelfasertypen in den fünf Muskeln von weiblichen und intakten männlichen Kontroll- und IGF1-transgenen Schweinen]

\begin{tabular}{|c|c|c|c|c|c|c|c|c|c|c|}
\hline \multirow[b]{2}{*}{ Muscle $^{\mathrm{a}}$} & \multirow{2}{*}{$\begin{array}{c}\text { Fiber } \\
\text { type }\end{array}$} & \multicolumn{2}{|c|}{ Gilts } & \multicolumn{2}{|c|}{ Boars } & \multicolumn{5}{|c|}{$P$-values } \\
\hline & & Control & Transgenic & Control & Transgenic & SEM & Gene $^{b}$ & $\operatorname{Sex}^{\mathrm{C}}$ & Fiber $^{\mathrm{d}}$ & $\begin{array}{c}\text { Gene } x \text { Sex } \\
\text { x Fiber }\end{array}$ \\
\hline \multirow[t]{3}{*}{ GC } & $\mathrm{SO}$ & 2788 & 3244 & 2972 & 3199 & 162 & & & & \\
\hline & FOG & 2978 & 2885 & 3107 & 3344 & 173 & 0.562 & 0.268 & $<0.001$ & 0.071 \\
\hline & $\mathrm{FG}$ & 4644 & 4806 & 5280 & 5129 & 219 & & & & \\
\hline \multirow[t]{3}{*}{$\mathrm{GM}^{\mathrm{e}}$} & SO & 2724 & 2999 & 2406 & 2702 & 152 & & & & \\
\hline & FOG & 2611 & 3198 & 2489 & 2657 & 169 & 0.100 & 0.131 & $<0.001$ & 0.081 \\
\hline & $\mathrm{FG}$ & 4094 & 5119 & 4381 & 4115 & 181 & & & & \\
\hline \multirow[t]{3}{*}{$\mathrm{LM}^{\mathrm{f}}$} & SO & 2443 & 3170 & 2763 & 3161 & 138 & & & & \\
\hline & FOG & 2097 & 2447 & 2500 & 2722 & 125 & 0.031 & 0.211 & $<0.001$ & 0.904 \\
\hline & FG & 3920 & 4212 & 4147 & 4238 & 143 & & & & \\
\hline \multirow[t]{3}{*}{$S T^{f}$} & SO & 4764 & 4525 & 4480 & 4790 & 250 & & & & \\
\hline & FOG & 3769 & 3797 & 3921 & 4096 & 272 & 0.856 & 0.739 & $<0.001$ & 0.320 \\
\hline & FG & 4551 & 4702 & 4844 & 4944 & 270 & & & & \\
\hline \multirow[t]{3}{*}{$S V^{f}$} & SO & 3041 & 3203 & 2845 & 3797 & 162 & & & & \\
\hline & FOG & 2437 & 2413 & 2204 & 2730 & 151 & 0.020 & 0.894 & $<0.001$ & 0.477 \\
\hline & $\mathrm{FG}$ & 3763 & 4085 & 3473 & 4039 & 170 & & & & \\
\hline
\end{tabular}

${ }^{\mathrm{a}} \mathrm{GC}=$ gastrocnemius, $\mathrm{GM}=$ gluteus medius, $\mathrm{ST}=$ semitendinosus, $\mathrm{LM}=$ longissimus, $\mathrm{SV}=$ serratus ventralis

${ }^{\mathrm{b}}$ Control vs. IGF1 transgenic.

c Gilts vs. boars.

d SO vs. FOG vs. FG.

e The data were grouped by sex and separate variance estimates were used in the analysis.

${ }^{\mathrm{f}}$ The data were grouped by treatment and separate variance estimates were used in the analysis.

\section{Muscle Fiber Areas}

Fiber areas of all three fiber types of LM and SV muscles were larger $(P \leq 0.031)$ in transgenic pigs than in control pigs (Table 6). The SO, FOG, and FG fibers of the GM muscle also tended $(P=0.100)$ to be larger in transgenic pigs than in control pigs. The 
impact of the transgene on FOG and FG fiber area of the GM muscle tended to be greater in gilts than boars (gene $\mathrm{x}$ sex $\mathrm{x}$ fiber interaction, $P=0.081$ ). The areas differed among the three fiber types with FG fiber area being larger than SO or FOG fibers in the GC, GM, LM, and SV muscles ( $P<0.001$ for each), whereas SO and FG fiber area in the ST muscle were similar and larger than the FOG fiber. None of the first order interactions were significant $(P>0.100)$.

Physical measurement data for the ST muscle are shown in Table 7 . The weight and estimated total number of fibers did not $(P \geq 0.186)$ differ for transgenic and control pigs. However, the girth of the ST was larger $(P=0.016)$ in transgenic pigs than in controls. The ST was longer $(P=0.041)$ in gilts than in boars and regardless of the sex tended $(P=0.097)$ to be shorter in transgenic than control pigs.

Table 7

Weight, girth, length, and estimated fiber number of the semitendinosus muscle of control and IGF1 transgenic pigs [Gewicht, Umfang, Länge und geschätzte Muskelfaseranzahl des semitendinosus Muskels von weiblichen und intakten männlichen Kontroll- und IGF1-transgenen Schweinen]

\begin{tabular}{lcccccccc}
\hline Item $^{\mathrm{a}}$ & \multicolumn{2}{c}{ Gilts } & \multicolumn{3}{c}{ Boars } & \multicolumn{3}{c}{$P$-values } \\
\cline { 2 - 9 } & Control & Transgenic & Control & Transgenic & SEM & Gene $^{\mathrm{b}}$ & Sex $^{\mathrm{c}}$ & Gene x Sex $^{-}$ \\
\hline Weight (g) & 441 & 462 & 427 & 444 & 14 & 0.186 & 0.292 & 0.893 \\
Girth (mm) & 219 & 234 & 224 & 240 & 6 & 0.016 & 0.432 & 0.939 \\
Length (mm) & 220 & 214 & 212 & 202 & 5 & 0.097 & 0.041 & 0.674 \\
Muscle fiber & 8.61 & 10.10 & 11.10 & 10.38 & 0.85 & 0.649 & 0.133 & 0.203 \\
number (x 10 $\left.{ }^{5}\right)^{\mathrm{d}}$ & & & & & & & & \\
\hline
\end{tabular}

${ }^{a}$ Carcass weight was used as covariate in the analysis.

${ }^{\mathrm{b}}$ Control vs. IGF1 transgenic.

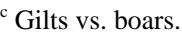

${ }^{\mathrm{d}}$ Estimated from the overall mean fiber area and the girth.

\section{Muscle hIGF1 mRNA}

Messenger RNA of hIGF1 was detected on Northern blots of total RNA from skeletal muscle of all transgenic pigs included in this study that was not detected in control pigs. Representative Northern blots for muscle hIGF1 mRNA are shown in Fig. 1. Transgenic progeny from one founder had multiple indistinct bands on the blots that reacted with the IGF1 probe in contrast to progeny from the other five founders in which only a single discrete band was found (Fig. 1c). Therefore, quantification of IGF1 mRNA abundance was performed on five skeletal muscles and the heart from transgenic progeny from only the five founders with a single discrete band.

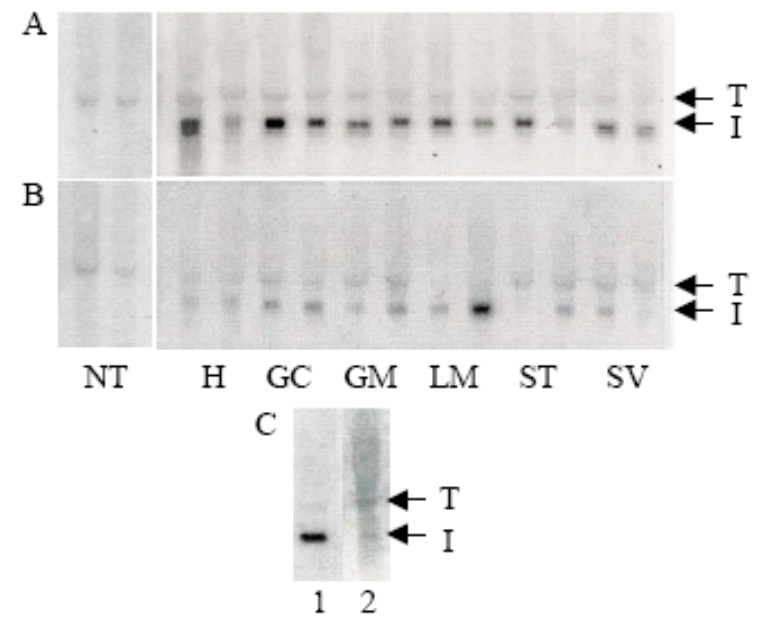

Fig. 1: Representative Northern blot analysis of IGF1 (I) and $\beta$-tubulin mRNA (T) in total RNA (20 $\mu$ g) from heart and skeletal muscles of non-transgenic and transgenic pigs. Panel A shows Northern blots from progeny of 
female founder 9901and panel B shows Northern blots from progeny of male founder 2006. Panels A and B show Northern blots of longissimus muscle (LM) from a non-transgenic (NT) boar (first lane) and gilt (second lane), and Northern blots for heart (H), gastrocnemius (GC), gluteus medius (GM), LM, semitendinosus (ST), and serratus ventralis (SV) from a transgenic boar and gilt, respectively. Panel C shows Northern blot of LM from a gilt sired by male founder 0701 (1) and a gilt sired by male founder 0702 (2)

[Northern Blot Analyse von IGF1 (I) und $\beta$-tubulin mRNA (T) in der totalen mRNA (20 $\mu$ g) von Herz- und Skelettmuskel von Kontroll- und IGF1-transgenen Schweinen. Im Bild A ist ein Northern Blot eines Nachkommens der Sau 9901 und in Bild B ist der Northern Blot eines Nachkommens des Ebers 2006 dargestellt.. Northern Blots vom langen Rückenmuskel (LM) von intakten männlichen (NT; erste Reihe in Blot A) und weiblichen Schweinen (NT; zweite Reihe in Blot B) und Northern blots vom Herz, gastrocnemius (GC), gluteus medius (GM), LM, semitendinosus (ST), and serratus ventralis (SV) Muskel von IGF1-transgenen intakten männlichen (Blot A) und IGF1-transgenen weiblichen Schweinen (Blot B). In Blot C sind Northern Blots des LM von zwei Sauen, die entweder mit dem Eber 0701 (1) oder dem Eber 0702 (2) gedeckt wurden]

Relative abundance of hIGF1 mRNA in the heart and five skeletal muscles are shown in Fig.2. Level of the IGF1 transgene expression differed $(P<0.05)$ among the progeny of the five founders and among the muscles that were evaluated. The level of IGF1 mRNA was higher $(P<0.05)$ in LM than GM, ST, and SV. Abundance of IGF1 mRNA did not $(P>0.05)$ differ among the other muscles, and did not differ $(P=$ 0.114 ) for heart vs. skeletal muscles. Although some muscles in boars tended to have higher IGF1 mRNA values than in gilts, the relative abundance did not $(P=0.169)$ differ.

Correlations of IGF1 mRNA abundance in each muscle and the average for all five skeletal muscles (ASM) with various carcass traits of the transgenic pigs are shown in Table 8. Levels of IGF1 expression in all skeletal muscles were positively $(P \leq 0.011)$ correlated with percentage of carcass lean $(r=0.597$ to 0.804$)$, and IGF1 expression levels in GC, GM, LM and ASM were positively $(P \leq 0.033)$ correlated with percentage of carcass water ( $r=0.519$ to 0.684$)$. In contrast, average backfat and P2 backfat thickness were negatively $(P \leq 0.051)$ correlated with abundance of IGF1 mRNA in GC, GM, LM, and ASM ( $r=-0.486$ to -0.629$)$, and percentages of carcass lipid and DXA fat were negatively $(P \leq 0.047)$ correlated with IGF1 mRNA level in LM and ASM ( $r=-0.488$ to -0.600$)$.

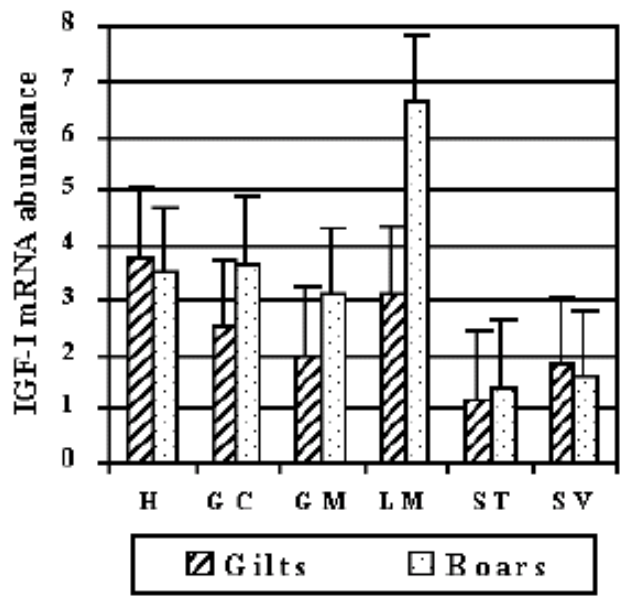

Fig. 2: Relative abundance of IGF1 mRNA in heart (H), gastrocnemius (GC), gluteus medius (GM), longissimus (LM), semitendinosus (ST), and serratus ventralis (SV) muscles of IGF1 transgenic gilts and boars [Relative IGF1 mRNA Abundanz im Herz (H), gastrocnemius (GC), gluteus medius (GM), longissimus (LM), semitendinosus (ST), and serratus ventralis (SV) Muskel von weiblichen und intakten männlichen Kontroll- und IGF1-transgenen Schweinen] 
Loin eye area, percentage carcass bone, carcass protein concentration, and mean fiber area of the muscle were not $(P \geq 0.064)$ correlated with the abundance of IGF1 mRNA in any of the five skeletal muscles. Except for a positive correlation with DXA bone content $(\mathrm{r}=0.488 ; P=0.047)$, IGF1 mRNA abundance in the heart was not $(P \geq$ $0.456)$ correlated with carcass measurements.

Table 8

Pearson's correlation coefficients for IGF1 mRNA abundance in heart and skeletal muscles with carcass measurements and mean fiber diameter for 17 IGF1 transgenic pigs [Pearson Korrelationskoeffizienten zwischen der relativen IGF1 mRNA Abundanz im Herz- und den fünf Skelettmuskeln und den Schlachtkörpereigenschaften sowie der durchschnittlichen Muskelfaserfläche von 17 IGF1 transgenen Schweinen]

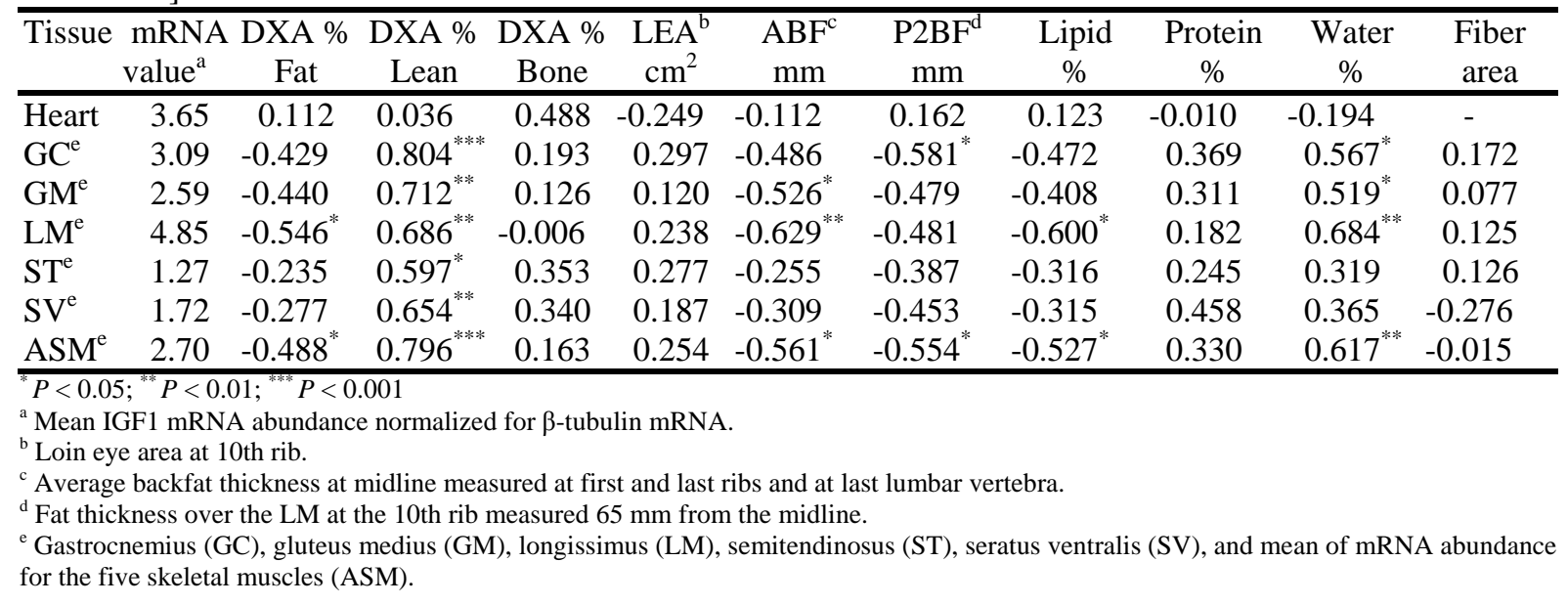

Correlations of IGF1 mRNA abundance in heart and ASM with organ weights for the transgenic pigs are shown in Table 9. Expression of IGF1 mRNA in the heart was positively correlated with the heart weight $(r=0.612, P=0.009)$. Weights of the adrenal, the liver, the ovary, and the testis were not $(P \geq 0.134)$ correlated with IGF1 mRNA levels, and spleen and kidney weight was approaching a positive $(P>0.078)$ correlation with IGF1 mRNA abundance in the heart $(r=0.492$ and 0.439 , respectively).

Table 9

Pearson's correlation coefficients for heart and ASM IGF1 mRNA abundance and organ weight [Pearson Korrelationskoeffizienten zwischen der relativen IGF1 mRNA Abundanz im Herz- und im Mittel der fünf Skelettmuskeln und den Organgewichten]

\begin{tabular}{lccccccc}
\hline Item & Adrenal & Heart & Liver & Kidney & Ovary & Spleen & Testis \\
\hline Heart mRNA & 0.070 & $0.612^{* *}$ & -0.259 & 0.439 & -0.458 & 0.492 & -0.540 \\
ASM mRNA $^{\text {a }}$ & 0.050 & 0.384 & 0.278 & 0.231 & -0.068 & -0.176 & -0.265 \\
\hline
\end{tabular}

${ }^{{ }^{*} P} P<0.01$

${ }^{\text {a }}$ Mean of IGF1 mRNA abundance for the five skeletal muscles

\section{Discussion}

Expression of an IGF1 transgene, which was directed specifically to skeletal muscle by skeletal $\alpha$-actin regulatory sequences, induced a shift from deposition of fat in the carcass to enhanced accretion of lean tissues. In the transgenic pigs the percentage of lean tissue in each of the four primary regions of the carcass and the loin eye area were all significantly elevated in contrast to significant reductions in average backfat and P2 backfat depth and percentages of carcass fat estimated by DXA in comparison to sibling controls. The magnitude of this shift in carcass composition was uniformly larger in gilts than in boars. This difference in response due to gender is in accordance 
with previous observations of differing gender responses to exogenous porcine growth hormone (pGH) administration to swine (CAMPBELL et al., 1989; KRICK et al., 1992; KLINDT et al., 1995a). These findings parallel our preliminary results with the IGF1 transgenic founder pigs (PURSEL et al., 1999) that generated the subjects used in the present study. The enhancement of carcass lean at the expense of carcass fat in the IGF1 transgenic pigs contrasts sharply from results obtained with exogenous IGF1 administration to pigs (WALTON et al., 1995; KLINDT et al., 1998) and lambs (COTTAM et al., 1992; MIN et al., 1996). KLINDT and coworkers (1998) observed an increase in leaf fat, empty body fat, and carcass and empty body energy content in pigs injected twice daily with recombinant (r)hIGF1 for four weeks. It seems unlikely that the dosage of rhIGF1 administered was insufficient to achieve a physiological response, because serum concentrations were elevated by $60 \%$ compared to untreated control pigs throughout the experiment.

We believe the divergence of our findings with those obtained with exogenously administered IGF1 is the direct result of the IGF1 transgene being expressed in the skeletal muscle where the active peptide induced a paracrine response. In the IGF1 transgenic pigs, circulating concentrations of IGF1 were only elevated by $19 \%$ in gilts and $11 \%$ in boars and plasma pGH concentrations were unaltered in comparison to sibling controls (PURSEL et al., 2004). In contrast, twice daily injections of IGF1 resulted in a $60 \%$ increase in serum IGF1, where it could potentially have an endocrine effect on skeletal muscle, but also depressed serum concentrations of pGH due to negative feedback on the hypothalamus/pituitary axis (KLINDT et al., 1998). It seems likely that the increase in leaf fat and empty body fat KLINDT et al. (1998) observed was a response to the depressed pGH rather than a direct lipogenic affect of IGF1, as suggested by the investigators.

The magnitude of alterations in carcass composition elicited by expression of the IGF1 transgene was somewhat lower than it has been reported for pigs administered exogenous growth hormone (see reviews by STEELE et al., 1994; ETHERTON and BAUMAN, 1998). However, direct comparisons of our results with those published for pGH-treated pigs are difficult, because results from those studies varied greatly depending on gender (CAMPBELL et al., 1989, 1990; KRICK et al., 1992; KLINDT et al., 1995a), duration of treatment (SMITH and KASSEN, 1990; KLINDT et al., 1995b), treatment dose (EVOCK et al., 1988; BEERMANN et al., 1990; THIEL et al., 1993), genetic background (CAMPBELL et al., 1989, 1990; KRICK et al., 1992; KLINDT et al., 1995a), slaughter weight (KANIS et al., 1990), and whether the pGH was administered by daily injection or by implant (BUONOMO et al., 1991). In addition, results in the present study varied considerably depending on the transgenic founder as well as the non-transgenic sire or dam of the progeny. Consequently, too few transgenic and control progeny of each sex were produced per founder to permit meaningful comparisons among founder lines.

Organomegaly is a common characteristic of pigs administered pGH. Depending on genetic background and gender, weight increases in heart by 2 to 33.5\%, in liver by 14.5 to $50 \%$, in kidney by 14 to $65 \%$, and in spleen by 1.3 to $35.7 \%$ were reported for GH treated pigs (KLINDT et al., 1995a). Similar increases in organ weights have also been reported for transgenic pigs (PURSEL et al., 1989, 1997), sheep (NANCARROW et al., 1991), and mice (HAMMER et al., 1985; POMP et al., 1992) expressing GH transgenes. In contrast, in the IGF1 transgenic pigs, the weight of the 
hearts was increased by only $6.5 \%$ in gilts and $9.1 \%$ in boars, weight of kidneys was increased by $18.3 \%$ in gilts and $4.6 \%$ in boars, and adrenals, liver, ovaries spleen, and testis did not differ from that of sibling controls. These findings are similar to the $7 \%$ increase in heart weight and the $19.6 \%$ increase in kidney weight in barrows that had been administered rhIGF1 twice daily for four weeks (KLINDT et al., 1998). In addition, COTTAM and coworkers (1992) reported that administration of rhIGF1 to weathers three times daily for 8 weeks resulted in a 10.5\% increase in kidney weight, no increase in heart or liver weight, and a $45 \%$ increase in spleen weight. Splenomegaly has also been reported in hypophysectomized and GH-deficient dwarf rats treated with IGF1 (GULER et al., 1988; SKOTTNER et al., 1989) and IGF1 transgenic mice (MATHEWS et al., 1988). The general lack of organomegaly in the IGF1 transgenic pigs as well as in IGF1-treated pigs and lambs is consistent with the inability of IGF1 to stimulate growth rate and improve efficiency of feed utilization.

An increase in incidence of gastric ulcers has been reported in GH-treated growing pigs (MCLAREN et al., 1990; SMITH and KASSON, 1990, 1991), in lactating sows (CROMWELL et al., 1989), and in transgenic pigs that were expressing high levels of bovine and ovine GH (PURSEL et al., 1989, 1997). The increase in stomach erosion score observed in the transgenic boars compared to the control boars was primarily the result of a high incidence in gastric ulcers in the 16 progeny of one founder (scores of 5 or 6 were found in 2 out of 5 control and 2 out of 4 transgenic gilts and 0 out of 2 control and 3 out of 5 transgenic boars). The low number of control boar progeny was the primary factor leading to the significant gene by sex interaction we obtained in this study. The erosion and ulceration that occurred in all pigs was most likely exacerbated by the fineness of the grind and pelleting of the feed (EISEMANN and ARGENZIO, 1999). In addition, the stress of being anesthetized and scanned by DXA at body weights of 60 and $90 \mathrm{~kg}$ and the day before slaughter may have contributed to the stomach erosion and ulceration.

With the histochemical staining procedure used in this study three muscle fiber types (SO, FOG, and FG) can be differentiated. However, results of recent studies revealed the existence of 4 muscle fiber types in the LM of pigs at $100 \mathrm{~kg}$ of BW, each one expressing a distinct myosin heavy chain isoform (I, IIa, IIx, and IIb; LEFAUCHEUR et al., 2002; LEFAUCHEUR, 2006; TONIOLO et al., 2004). LEFAUCHEUR et al. (2002) reported that compared with IIb, IIx muscle fibers display also a moderate succinic dehydrogenase staining. Thus, the FOG fibers reported in this study actually contain two distinct populations of myofibers (IIa and IIx). Therefore, the current results do not allow to estimate to what extent IGF1 expression determined the size and the distribution of the IIa and IIx fibers and how the higher expression level in the muscle affected muscle fiber conversion, which follows the obligatory pathway of myosin heavy chain transition (I $\leftrightarrow$ IIa $\leftrightarrow$ IIx $\leftrightarrow$ IIb; SCHIAFFINO and REGGIANI, 1994; TONIOLO et al., 2004).

Expression of the IGF1 transgene in the five skeletal muscles examined resulted in a significant increase in fiber area (across all three fiber types) in LM and SV muscles, approached significance in GM, and a trend for an increase in GC and ST muscles as compared to sibling control pigs. The overall percentage of fiber area increase among the muscles of transgenic pigs was inversely related to the average fiber area in control pigs, i.e., rank for average fiber area was $\mathrm{SV}<\mathrm{LM}<\mathrm{GM}<\mathrm{GC}<\mathrm{ST}$ and increases in fiber area were 14.1, 11.6, 11.1, 3.8, and 2.0\%, respectively. In comparison to control 
pigs, the overall increase in fiber areas for transgenic gilts and boars were $16.2 \%$ and $7.6 \%$ for LM and $0.5 \%$ and $4.4 \%$ for ST, respectively, which closely paralleled the $19.9 \%$ and $9.6 \%$ increase in loin eye areas and $2.3 \%$ and $5.0 \%$ increase in ST weight. In pigs administered $\mathrm{GH}$, an increase in fiber area that paralleled increased muscle weight and loineye area (LEA) was reported for ST (BEERMANN et al., 1990) and LM (SOLOMON et al., 1988). 1988). Also, BIEREDER et al. (1999) reported that a group of pigs with high mean diameter of muscle fibers in the $M$. triceps brachii had a significantly higher IGF1 concentration in the plasma than did a group of pigs in the same study with low muscle fiber diameter in the same muscle.

In the present study expression of the IGF1 transgene in the five skeletal muscles did not alter the relative percentages of the three fiber types that were distinguished by staining reaction. We did not see a shift in myofiber type toward more oxidative fiber types that COLEMAN et al. (1995) observed in the gluteus muscles of IGF1 transgenic mice. Most investigators have not observed shifts in the distribution of fiber types in pigs administered GH (SOLOMON et al., 1988, 1990; BEERMANN et al., 1990; ONO et al., 1995). A shift in distribution from FG to SO was reported for LM (SOLOMON et al., 1991) and for ST (SOLOMON et al., 1994) when exogenous pGH was administered or evaluated in younger pigs (50 - $60 \mathrm{~kg} \mathrm{BW}$ ).

Although shear force tenderness did not differ between transgenic and control pigs, the shear values were considerably higher than one typically observes for pork LM muscles (SOLOMON et al., 1994). These higher shear values may be a result of prerigor shortening phenomenon since LM muscles were excised from the respective carcasses within 15 min post-exsanguinations and thus removed from any restraints while being stored for $5 \mathrm{~d}$ at $2^{\circ} \mathrm{C}$. Both the transgenic and control LM samples had shear values averaging 73.6 $\mathrm{N}$ and all LM muscles were handled the same way due to the protocol of the study. Previous studies involving transgenic pigs with $\mathrm{GH}$ transgenes (SOLOMON et al., 2000) exhibited shear values averaging $34.3 \mathrm{~N}$, however, those LM samples were not removed from the carcasses until after $48 \mathrm{~h}$ postmortem. Perhaps the high shear values for the pigs in this study would be mitigated if the muscle samples were left on the carcass for at least the period of time postmortem for the muscle to go into rigor while still attached to the bone and thus more closely resemble meat industry procedures.

The relative abundance of IGF1 mRNA in the skeletal muscles for the progeny of the five founders generally agreed with the relative abundance observed in the parental founders (PURSEL et al., 1999). In addition, no IGF1 mRNA was detected in skeletal muscle of the three founder transgenic boars or their progeny, and the carcass composition of these pigs did not differ from their non-transgenic siblings; data from those non-expressing animals were not included in this paper.

Endogenous IGF1 mRNA was not detected in skeletal muscle of non-transgenic pigs even though the IGF1 probe we used was not specific for the IGF1 transgene. Several factors may have been responsible for our failure to detect endogenous IGF1 mRNA in skeletal muscle of non-transgenic pigs and may have diminished the abundance in transgenic pigs. Certainly the time required to dissect and process the multiple muscle samples from each pig was greater in our study than in others in which a single muscle sample was processed (LEAMAN et al., 1990; COLEMAN et al., 1994; PENG et al., 1996). In addition, our pigs were fasted for $42 \mathrm{~h}$ before slaughter compared to a $16 \mathrm{~h}$ fast period reported by PENG et al. (1996). LEAMAN et al. (1990) found that fasting 
significantly reduced abundance of IGF1 mRNA in heart and skeletal muscle of young pigs, and plasma concentrations of IGF1 are known to decline progressively with duration of fasting in humans (SAVENDAHL and UNDERWOOD, 1999). Furthermore, abundance of IGF1 mRNA has also been reported to decline with age of pigs from birth to 6 months (PENG et al., 1996).

The significant positive correlations of transgene mRNA abundance in skeletal muscle with carcass lean and heart mRNA level with heart weight combined with significant negative correlations of transgene mRNA levels with several measures of fat deposition provides strong evidence that IGF1 expression was functioning in a paracrine manner as we had originally intended. These collective data also supports growing recognition that the paracrine actions of IGF1 have a greater impact on growth stimulation than circulating concentrations of IGF1.

These findings show conclusively that IGF1 can have a major affect on muscle development and carcass composition in swine when delivery is via a muscle-specific transgene. Whether the effects we observed were totally the result of paracrine action or both paracrine and endocrine is an open question because plasma IGF1 was 19 and $11 \%$ higher in transgenic gilts and boars, respectively, than in non-transgenic siblings (PURSEL et al., 2004). However, the experiments in which hepatic IGF1 expression was eliminated in mice through knock-out technology provided direct evidence that IGF1 acts locally in a paracrine/autocrine fashion to mediate GH-induced somatic growth, rather than by IGF1 produced by the liver acting in an endocrine fashion to stimulate growth of somatic tissues (SJOGREN et al., 1999; YAKAR et al., 1999).

\section{Acknowledgments}

We thank Marsha Campbell, Janet Eastridge, Nancy Faulkner, and Leah Schulman for technical assistance; and Delbert Parsons, James Piatt, and Ray Zephir for abattoir assistance.

\section{References}

BEERMANN, D.H.; FISHELL, V.K.; RONEKER, K.; BOYD, R.D.; ARMBRUSTER, G.; SOUZA, L.: Dose-response relationships between porcine somatotropin, muscle composition, muscle fiber characteristics and pork quality. J. Anim. Sci., 68 (1990), 2690-2697.

BUONOMO, F.C.; KLINDT, J.; YEN, J.T.:

Effects of exogenous porcine somatotropin (PST) on growth, carcass and metabolic parameters in genetically obese barrows: Comparison of daily injection versus continuous release. J. Anim. Sci., 69 (Suppl. 1) (1991), 306 (Abstr.).

BIEREDER, S.; WICKE, M.; LENGERKEN, G. v.; SCHNEIDER, F.; KANITZ, W.:

Muskelwachstum und IGF-I bei Schweinen unterschiedlichen Geschlechts. Arch. Tierz., Dummerstorf 42 (1999), 619-628.

CAMPBELL, R.G., STEELE, N.C.; CAPERNA, T.J.; MCMURTRY, J.P.; SOLOMON, M.B.; MITCHELL, A.D.:

Interrelationships between sex and exogenous growth hormone administration on performance, body composition and protein and fat accretion of growing pigs. J. Anim. Sci., 67 (1989), 177-186.

CAMPBELL, R.G.; JOHNSON, R.J.; KING, R.H.; TAVERNER, M.R.:

Effects of gender and genotype on the response of growing pigs to exogenous administration of porcine growth hormone. J. Anim. Sci., 68 (1990), 2674-2681.

COLEMAN, M.E.; DEMAYO, F.; YIN, K.C.; LEE, H.M.; GESKE, R.; MONTGOMERY, C.; SCHWARTZ, R.J.:

Myogenic vector expression of insulin-like growth factor I stimulates muscle cell differentiation and myofiber hypertrophy in transgenic mice. J. Biol. Chem., 270 (1995), 12109-12116.

COLEMAN, M.E.; RUSSELL, L.; ETHERTON, T.D.: 
Porcine somatotropin (pST) increases IGF-I mRNA abundance in liver and subcutaneous adipose tissue but not in skeletal muscle of growing pigs. J. Anim. Sci., 72 (1994), 918-924.

COTTAM, Y.H.; BLAIR, H.T.; GALLAHER, B.W.; PURCHAS, R.W.; BREIER, B.H.; MCCUTCHEON, S.N.; GLUCKMAN, P.D:

Body growth, carcass composition, and endocrine changes in lambs chronically treated with recombinantly derived insulin-like growth factor-I. Endocrinology, 130 (1992), 2924-2930.

CROMWELL, G.L.; STAHLY, T.S.; EDGERTON, L.A.; MONEQUE, H.J.; BURNELL, T.W.; SCHENCK, B.C.; ELKINS, T.T.:

Recombinant porcine somatotropin for lactating sows. J. Anim. Sci., 67 (Suppl 1) (1989), 257 (Abstr.).

EISMANN, J.H.; ARGENZIO, R.A.:

Effect of diets differing in propensity to promote gastric lesions on defense systems in gastric mucosae. J. Anim. Sci., 77 (1999), 2715-2720.

ETHERTON, T.D.; BAUMAN, D.E.:

Biology of somatotropin in growth and lactation of domestic animals. Physiogical Reviews. 78 (1998), 745-761.

EVOCK, C.M.; ETHERTON, T.D.; CHUNG, C.S., IVY R.E.:

Pituitary porcine growth hormone (pGH) and a recombinant pGH analog stimulate pig growth performance in a similar manner. J. Anim. Sci., 66 (1988), 1928-1941.

FIELD, R.A.; RILEY, M.L.; MELLO, F.C.; CORBRIDGE, M.H.; KOTULA, A.W.:

Bone composition in cattle, pigs, sheep and poultry. J. Anim. Sci., 39 (1974), 493-499.

FOLCH, J.; LEES, M.; SLOAN-STANLEY, G.H.:

A simple method for the isolation and purification of total lipids from animal tissues. J. Biol. Chem., 226 (1957), 497-509.

GULER, H.P.; ZAPF, J.; SCHEIWILLER, E.; FROESCH, E.R.:

Recombinant human insulin-like growth factor I stimulates growth and has distinct effects of organ growth size in hypophysectomized rats. Proc. Natl. Acad. Sci., USA, 85 (1988), 4889-4893.

HAMMER, R.E.; BRINSTER, R.L.; PALMITER, R.D.:

Use of gene transfer to increase animal growth. Cold Spring Harbor Symposium on Quantitative Biology, 50 (1985), 379-387.

JANSEN M.; VAN SCHAIK, F.M.; RICKER, A.T.; BULLOCK, B.; WOODS, D.E.; GABBAY, K H.;

NUSSBAUM, A.L.; SUSSENBACH, J S.; VAN DEN BRANDE, J.L.:

Sequence of cDNA encoding human insulin-like growth factor I precursor. Nature (London), 30 (1983), 609-611.

JEBB, S.; GOLDBERG, G.R.; JENNINGS, G.; ELIA, M.:

Dual-energy X-ray absorptiometry measurements of body composition: Effects of depth and tissue thickness, including comparisons with direct analysis. Clin. Sci., 88 (1995), 319-324.

KANIS, E.; NIEUWHOF, G.; DE GREEF, K.H.; VAN DER HEL, W.; VERSTEGEN, M.W.A.; HUISMAN, J.; VAN DER WAL, P.:

Effect of recombinant porcine somatotropin on growth and carcass quality in growing pigs: Interactions with genotype, gender and slaughter weight. J. Anim. Sci., 68 (1990), 1193-1200.

KLINDT, J.; BUONOMO, F.C.; YEN, J.T.; BAILE, C.A.:

Growth performance, carcass characteristics, and sensory attributes of boars administered porcine somatotropin by sustained-release implant for different lengths of time. J. Anim. Sci., 73 (1995a), 35853595.

KLINDT, J.; BUONOMO, F.C.; YEN, J.T.:

Administered porcine somatotropin by sustained-release implant: Growth, carcass characteristics, and sensory responses in crossbred white and genetically lean and obese boars and gilts. J. Anim. Sci., 73 (1995b), 1327-1339.

KLINDT, J.; YEN, J.T.; BUONOMO, F.C.; ROBERTS, A.J.; WISE, T.:

Growth, body composition, and endocrine responses to chronic administration of insulin-like growth factor I and (or) porcine growth hormone in pigs. J. Anim. Sci., 76 (1998), 2368-2381.

KRICK, B.J.; RONEKER, K.R.; BOYD, R.D.; BEERMANN, D.H.; DAVID, P.J.; MEISINGER, D.J.: Influence of genotype and sex on the response of growing pigs to recombinant porcine somatotropin. $\mathrm{J}$. Anim. Sci., 70 (1992), 3024-3034.

LEAMAN, D.W.; SIMMEN, F.A.; RAMSEY, T.G.; WHITE, M.E.: Insulin-like growth factor-I and -II messenger RNA expression in muscle, heart, and liver of streptozotocin-diabetic swine. Endocrinology, 126 (1990), 2850-2857.

LEFAUCHEUR, L. Myofibre typing and its relationships to growth performance and meat quality. Arch. Tierz., Dummerstorf 49 (2006) Special Issue, 4-17.

LEFAUCHEUR, L.; ECOLAN, P.; PLANTARD, L.; GUEGUEN, N.: 
New insights into muscle fiber types in the pig. Journal of Histochemistry and Cytochemistry $\mathbf{5 0}$ (2002), 719-730.

MATHEWS, L.S.; HAMMER, R.E.; BEHRINGER, R.R.; D’ERCOLE, A.J.; BELL, G.I.; BRINSTER, R.L.; PALMITER, R.D.:

Growth enhancement of transgenic mice expressing human insulin-like growth factor-I. Endocrinology, 123 (1988), 2827-2833.

MCLAREN, D.G.; BECHTEL, P.J.; GREBNER, G.L.; NOVAKOFSKI, J.; MCKEITH, F.K.; JONES, R.W.; DALRYMPLE, R.H.; EASTER, R.A.:

Dose response in growth of pigs injects daily with porcine somatotropin from 57 to 103 kilograms. J. Anim. Sci., 68 (1990), 640-651.

MIN, S.H.; MACKENZIE, D.D.; BREIER, B.H.; MCCUTCHEON, S.N.; GLUCKMAN, P.D.:

Responses of young energy-restricted sheep to chronically administered insulin-like growth factor I (IGF-I): evidence that IGF-I suppresses the hepatic growth hormone receptor. Endocrinology, 137 (1996), 1129-1137.

MITCHELL, A.D.; SCHOLZ, A.M.; PURSEL, V.G.; EVOCK-CLOVER, C.M.:

Composition analysis of pork carcasses by dual-energy X-ray absorptiometry. J. Anim. Sci., 76 (1998), 2104-2114.

MITCHELL, A.D.; STEELE, N.C.; SOLOMON, M.B.; ALILA, H.W.; LINDSEY, T.O.; CRACKNELL, V.: Influence of dietary background on the response of pigs to the $\beta$-adrenergic agonist BRL-47672. J. Anim. Sci., 72 (1994), 1516-1521.

NANCARROW, C.D.; MARSHALL, J.T.A.; CLARKSON, J.L.; MURRAY, J.D.; MILLARD, R.M.; SHANAHAN, C.M.; WYNN, P.C.; WARD, K A.:

Expression and physiology of performance regulating genes in transgenic sheep. J. Reprod. Fert., 43 (Suppl.), (1991), 277-291.

ONO, Y.; SOLOMON, M.B.; EVOCK-CLOVER, C.M.; STEELE, N.C.; MARUYAMA, K.:

Effects of porcine somatotropin administration on porcine muscles located within different regions of the body. J. Anim. Sci., 73 (1995), 2282-2288.

PENG, M.; PELLETIER, G.; PALIN, M.F.; VERONNEAU, S.; LEBEL, D.; ABRIBAT, T.:

Ontogeny of IGFs and IGFBPs mRNA levels and tissue concentrations in liver, kidney and skeletal muscle of pig. Growth Dev. Aging, 60 (1996), 171-187.

PURSEL, V.G.; MITCHELL, A.D.; BEE, G.; ELSASSER, T.H.; MCMURTRY, J.P.; WALL, R.J.; COLEMAN, M.E.; SCHWARTZ, R.J.:

Growth and tissue accretion rates of swine expressing an insulin-like growth factor I transgene. Anim. Biotechnology, 15 (2004), 33-45.

PURSEL, V.G.; PINKERT, C.A.; MILLER, K.; BOLT, D.J.; CAMPBELL, R.G.; PALMITER, R.D.; BRINSTER, R.L.; HAMMER, R.E.: Genetic engineering of livestock. Science, 244 (1989), 1281-1288.

PURSEL, V.G.; WALL, R.J.; MITCHELL, A.D.; ELSASSER, T.H.; SOLOMON, M.B.; COLEMAN, M.E.; DEMAYO, F.; SCHWARTZ, R.J.:

Expression of insulin-like growth factor-I in skeletal muscle of transgenic swine. In: Transgenic Animals in Agriculture (Ed.: J.D. Murray, G.B. Anderson, M.M. McGloughlin and A.M. Oberbauer), CAB International, Wallingford, UK (1999), 131-144.

PURSEL, V.G.; WALL, R.J.; SOLOMON, M.B.; BOLT, D.J.; MURRAY, J.D.; WARD, K.A.: Transfer of an ovine metallothionein-ovine growth hormone fusion gene into swine. J. Anim. Sci., 75 (1997), 2208-2214.

SAVENDAHL, L.; UNDERWOOD, L.E.:

Fasting increases serum total cholesterol, LDL cholesterol and apolipoprotein B in healthy, nonobese humans. J. Nutr., 129 (1999), 2005-2008.

SCHIAFFINO, S.; REGGIANI, C.: Myosin isoforms in mammalian skeletal muscle. J. Appl. Physiol. 77 (1994), 493-501.

SKOTTNER, A.; CLARK, R.G.; FRYKLUND, L.; ROBINSON, I.C.A.F.:

Growth responses in a mutant dwarf rat to human growth hormone and recombinant human insulin-like growth factor I. Endocrinology, 124 (1989), 2519-2526.

SMITH, V.G.; KASSON, C.W.:

Growth performance and carcass characteristics of pigs administered recombinant porcine somatotropin during 30 to 110 kilogram live weight. J. Anim. Sci., 68 (1990), 4110-4116.

SMITH, V.G.; KASSON, C.W.:

The interrelationship between crude protein and exogenous porcine somatotropin on growth, feed and carcass measurements of pigs. J. Anim. Sci., 69 (1991), 571-577.

SJOGREN, K.; LIU, J.L.; BLAD, K.; SKRTIC, S.; VIDAL, O.; WALLENIUS, V.; LEROITH, D.; TORNELL, J.; ISAKSSON, O.G..; JANSSON, J.O; OHLSSON, C.: 
Liver-derived insulin-like growth factor I (IGF-I) is the principal source of IGF-I in blood but is not required for postnatal body growth in mice. Proc. Natl. Acad. Sci.. USA, 96 (1999), 7088-7092.

SOLOMON, M.B.; CAMPBELL, R.G.; STEELE, N.C.:

Effect of sex and exogenous porcine somatotropin on longissimus muscle fiber characteristics of growing pigs. J. Anim. Sci., 68 (1990), 1176-1181.

SOLOMON, M.B.; CAMPBELL, R.G.; STEELE, N.C.; CAPERNA, T.J.:

Effects of exogenous porcine somatotropin administration between 30 and 60 kilograms on longissimus muscle fiber morphology and meat tenderness of pigs grown to 90 kilograms. J. Anim. Sci., 69 (1991), 641-645.

SOLOMON, M.B.; CAMPBELL, R.G.; STEELE, N.C.; CAPERNA, T.J.; MCMURTRY, J.P.:

Effect of feed intake and exogenous porcine somatotropin on longissimus muscle fiber characteristics of pigs weighing $55 \mathrm{~kg}$ live weight. J. Anim. Sci., 66 (1988), 3279-3284.

SOLOMON, M.B.; CAPERNA, T.J.; MROZ, R.J.; STEELE, N.C.:

Influence of dietary protein and recombinant porcine somatotropin administration in young pigs: III. Muscle fiber morphology and meat tenderness. J. Anim. Sci., 72 (1994), 615-621.

SOLOMON, M.B.; DUNN, M.C.:

Simultaneous histochemical determination of three fiber types in single sections of ovine, bovine and porcine skeletal muscle. J. Anim. Sci., 66 (1988), 255-264.

SOLOMON, M.B.; EASTRIDGE, J.S.; PURSEL, V.G.; BEE, G.; MITCHELL, A.D.:

Implications of biotechnology: meat quality and value. Proceedings of 53rd Reciprocal Meat Conference, American Meat Science Association, (2000), 94-102.

STEELE, N.C.; BOYD, R.D.; CAMPBELL, R.G.:

Growth, metabolic modifiers, and nutrient considerations. In: Low-Fat Meats Design Strategies and Human Implications. (Ed: H.D. Hafs \& R.G. Zimbelman), Academic Press, San Diego, CA, (1994), 167-189.

THIEL, L.F.; BEERMANN, D.H.; KRICK, B.J.; BOYD, R.D.:

Dose-dependent effects of exogenous porcine somatotropin on the yield, distribution and proximate composition of carcass tissues in growing pigs. J. Anim. Sci., 71 (1993), 827-835.

TONIOLO, L.; PATRUNO, M.; MACCATROZZO, L.; PELLEGRINO, M.A.; CANEPARI, M.; ROSSI, R.;

D'ANTONA, G.; BOTTINELLI, R.; REGGIANI, C.; MASCARELLO, F.:

Fast fibres in a large animal: fibre types, contractile properties and myosin expression in pig skeletal muscles. J. Exp. Biol. 207 (2004), 1875-1886.

WALTON, P.E.; DUSHEA, F.R.; BALLARD, F.J.:

In vivo actions of IGF analogues with poor affinities for IGFBPs: Metabolic and growth effects in pigs of different ages and GH responsiveness. Progress in Growth Factor Research, 6 (1995), 385-395.

YAKAR, S.; LIU, J.L.; STANNARD, B.; BUTLER, A., ACCILI, D.; SAUER, B.; LEROITH, D.:

Normal growth and development in the absence of hepatic insulin-like growth factor I. Proc. Natl. Acad. Sci. USA, 96 (1999), 7324-7329.

\section{Received: 2007-07-26}

Accepted: 2007-08-20

Author's addresses

Dr. GIUSEPPE BEE, Agroscope Liebefeld Posieux, Research Station ALP,

1725 POSIEUX, SWITZERLANDＩＥ-Mail: giuseppe.bee@alp.admin.ch

Dr. VERNON G. PURSEL, Dr. ALVA D. MITCHELL, Dr. MORSE B. SOLOMON, Dr. ROBERT J. WALL, United States Department of Agriculture, Agricultural Research Service, Livestock and Poultry Science Institute, BELTSVILLE, MD 20705, USA

E-Mail: alva.mitchell@ars.usda.gov

Dr. KIMIAKI MARUYAMA, Department of Life Science, Meiji University,Tama, KAWASAKI, JAPAN

Dr. KEVIN D. WELLS, Revivicor, VPI Corporate Research Center, 1700 Kraft Drive, Suite 2400 BLACKSBURG, VA 24060, USA

Dr. MICHAEL E. COLEMAN, Gencell SAS, 94400 VITRY SUR SEINE, FRANCE

Dr. ROBERT J. SCHWARTZ, Baylor College of Medicine, HOUSTON, TX 77030, USA 